\title{
Spatio-temporal dynamics of land use changes in response to external pressures in Oman: Greenhouse cropping as an example
}

\author{
Michael L. Deadman ${ }^{1^{*}}$, Abdullah M. Al-Sadi ${ }^{1}$, Malik M. Al-Wardi ${ }^{2}$, Khalifa S.M. Al-Kiyumi ${ }^{3}$, \\ W.M. Deadman ${ }^{4}$, and Fahad A. Al Said ${ }^{1}$

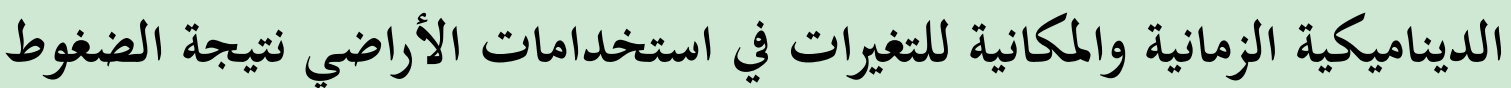

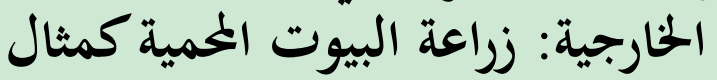$$
\text { مايكل ديدمان1" وعبدالله السعدي1 ومالك الوردي2 وخليفة الكيومي3 ووليام ديدمان4 وفهد آل سعيد1 }
$$

ABSTRACT. Further from the northern coast of Oman new farm developments were more frequent than closer to the coast; they were also larger. The density of farms was highest close to Muscat although the distance enclosing $50 \%$ of farms had shifted away from Muscat during the study period. The dominance of Muscat is likely to be related to access to markets and infrastructure development. The increase in groundwater salinity was also highest close to Muscat and may be responsible for the shift in greenhouse density. Salinization of groundwater is severe close to the coast and was responsible for the reduced density of greenhouses near the coast. Land abandonment was highest close to Muscat and to the coast, reflecting changes in groundwater salinity and urbanization pressure. Less evidence was available for a direct shift from farmland to urban land use. Recent urban developments were largely located in areas already abandoned by agriculture. The paper also discusses likely future trends in land use change given that Oman's population is increasing at over $2 \%$ annually and demand for urban land is increasing. The identification of a "salinity corridor" within which much of the future land use change may occur is discussed.

KEYwORDS: Land cover; Greenhouse protected cropping; Agricultural intensification; Groundwater salinity; Urbanization; Transport infrastructure.

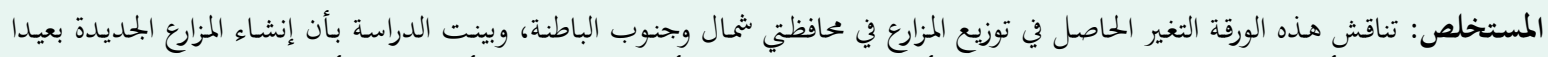

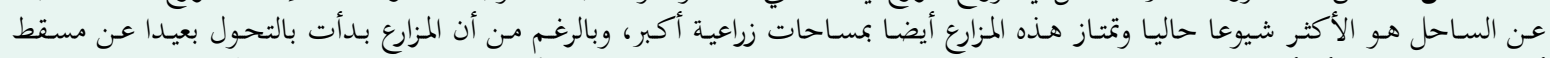

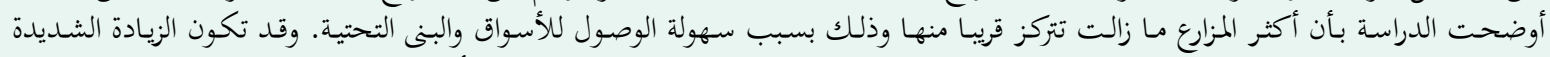

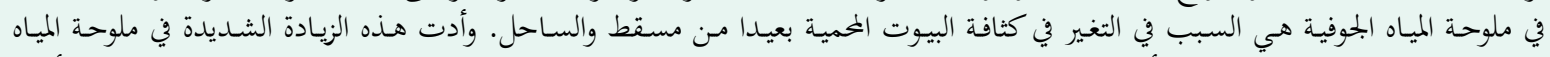

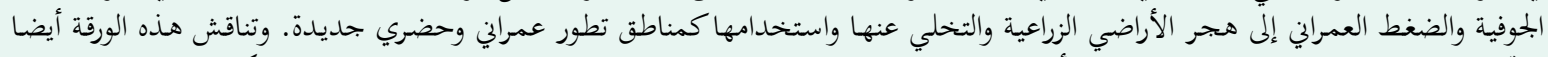

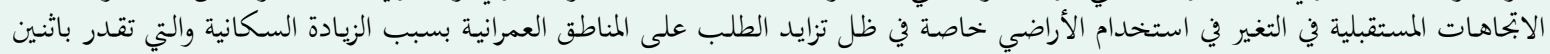

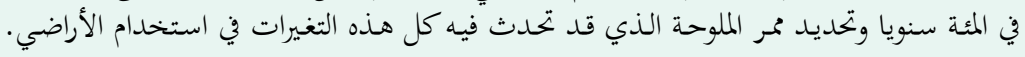

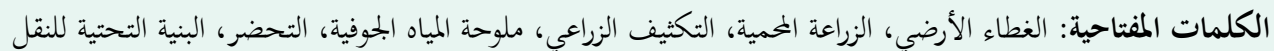

\section{Introduction}

$\mathrm{U}$ nder the theoretical umbrella of land use/land cover change research, much attention has naturally focused on agro-forestry dynamics, including deforestation (Asner et al., 2005; Nepstad et al., 1999), agricultural expansion (Maeda et al., 2010) or intensification (Lambin et al., 2000; Armsworth et al., 2006), desertification (Pando-Moreno et al., 2004), urbanization of productive agricultural land (Seto et al., 2000; Seto et al., 2002; Seto et al., 2010) and the causes and consequences of farm abandonment (Mottet et al.,

\footnotetext{
${ }^{* 1}$ Michael Deadman ( Sultan Qaboos University, College of Agricultural and Marine Sciences, Department of Crop Sciences . Box 34, Al-Khod 123. Sultanate of Oman. email: mikedead@squ.edu.om. ${ }^{2}$ SQU, CAMS, Department of Soils, Water and Agricultural Engineering. ${ }^{3}$ Ministry of Agriculture and Fisheries Wealth, P O Box 467, Muscat 113, Sultanate of Oman. ${ }^{4}$ Department of Archaeology, Durham University, South Road, Durham, DH1 3LE, UK
}

2006; Diaz et al., 2011). As a science and subject for debate on global sustainability issues, land use/land cover studies seek to motivate greater observation and monitoring of land changes. It also promotes understanding of changes as a coupled human-environment system, development of spatially explicit models of land change and integrated assessments of system outcomes, such as vulnerability, resilience, or sustainability (Turner et al., 2007).

Across the Arabian Peninsula little attention has been paid to the driving forces and consequences of land use/land cover change. This is remarkable given the dramatic economic and societal changes that have taken place in these "high-income less developed" (Odedokun, 1996) countries in relatively short periods of time; countries where rates of population growth are globally amongst the highest. The mean rate of population increase for the Gulf Cooperation Council (GCC) countries, plus Yemen, is variously estimated at 2.2 or $2.3 \%$ 
annually (CIA, 2010; UN, 2007). Omar et al. (1998) have described a scenario in Kuwait where irrigated desert lands, with minimal rainfall and loss of natural vegetation to crop production activities, are prone to soil erosion, sand encroachment and increasing both soil and groundwater salinity. This pattern of change is reflected, at least in some of its manifestations, across the region. Salinization of irrigated land is an issue especially where coastal aquifers are depleted by agriculture and other activities at a rate that is substantially faster than rain-mediated recharge. Seawater intrusion into the aquifer due to excessive pumping is a direct and well documented consequence not just in the Middle East (Kacimov et al., 2009) but also elsewhere where river water levels have fallen (Kotera et al., 2008). Salinization might therefore be considered as a potentially major driver behind land use change.

As an increasingly important sector of land-based agriculture, greenhouse cropping has expanded rapidly since 2000. The technology was introduced into Oman in the late 1980s to help relieve some of the constraints facing the agricultural sector, in particular the hot climate and shortage of water (MAF, 1994). Given the rapidly changing dynamics of greenhouse utilization, the sector might be considered as a proxy for intensive agriculture and thus serve as a tool for studying the vectors of land-use change, at least within the Al Batinah region where most greenhouses are located.

Significant changes in the total number of greenhouses have been brought about because many farmers have realized the importance of this technology for their financial benefit. Furthermore, the Ministry of Agriculture and Fisheries (MAF) has encouraged land use change by offering monetary incentives in the form of subsidies for greenhouse construction, resulting in a boom in development conceptually similar to that observed elsewhere (MacLeod and Moller, 2006; see also Lambin et al., 2001) and perhaps best expressed as agricultural intervention towards productivism as defined by Wilson and Rigg (2003). Although in New Zealand subsidies seemingly caused intensification (MacLeod and Moller, 2006), in Oman there is a potential disjoin between so-called intensification represented by greenhouse construction and the destination of extensive agriculturalists displaced by greenhouse crop producers.

The Al Batinah Governorates represent the most agriculturally active region of Oman; it is subdivided into administrative districts (Wilaya, sing. = Wilayat, Fig. 1a) each having their own local markets, but with the western-most of these closer to Dubai in the United Arab Emirates than to Muscat. The marketing of farm produce from these western Wilaya is likely to be influenced by Dubai as much as by Muscat (Zekri, 2010). Across most of the region the majority of greenhouse crop production is marketed locally or at Al Mawaleh central market in Muscat Municipality, close to the high-density population of the capital area (Zekri, 2010). Al Mawaleh is a significant marketing outlet for all fruit and vegetables produced across Oman, handling in excess of 10,000 $t$ of fruit and vegetables monthly and integrating with other, smaller markets in Muscat and elsewhere (Omezzine et al., 2002). Al Mawaleh central market, specifically, and the urban spread of Muscat in general, might therefore be expected to emerge as one of the major driving forces behind major land use change at the rural/peri-urban interface close to the capital area.

Al Batinah is very much a transition zone where change is unlikely to be simple and unidirectional, but complex and in all probability influenced by a multiplicity of regional as well as local factors (Amanor and Pabi, 2007). The urbanization of agricultural land, especially around the periphery of the capital area is exerting pressures on current land use distribution. Oman's population is increasing at approximately $2 \%$ annually (CIA, 2010; UN, 2007) greatly increasing the demand for housing. Oman is committed to diversifying the economy away from hydrocarbon related exports (Fasano and Iqbal, 2003) and as non-hydrocarbon revenues have grown (IMF, 2008), the recent years have seen increases in both the large and small to medium sized industrial enterprises, further increasing demand for building land beyond the common boundary shared by Muscat and Wilayat Barka. Such rapid urbanization might therefore be identified as a major driving force behind land use change in Al-Batinah.

Salinity is a threat to the permanence of irrigated agriculture in arid and semi-arid regions of the world whether rainfall induced (Asseng et al., 2010) or brought about by seawater intrusion into local aquifers (Ghassemi et al., 1997). The latter inductor is dominant in Oman and in similar regions of the world. The over abstraction of groundwater for irrigation purposes has resulted in high water salinity in many parts of Oman, especially in the coastal zone of Al-Batinah, due to sea water intrusion. The Water Resources Master Plan (MWR, 2000) reported that the total deficit in fresh water for some parts of Al-Batinah amounted to $92.8 \mathrm{Mm}^{3}$ and sea water intrusion accounted for $45.8 \mathrm{Mm}^{3}$ of water recharged into the aquifers. Al-Barwani and Helmi (2006) studied water salinity changes and rainfall in South Al-Batinah region from 1989 to 2005 and reported that salinity intrusion and groundwater salinity has increased despite the high rainfall events between 1995 and 1997. They have also reported that the area covered by high water salinity $\left(>16 \mathrm{dS} \cdot \mathrm{m}^{-1}\right.$ ) has increased from $17 \%$ in 2000 to $32 \%$ in 2005 in Barka, while it has increased from $29 \%$ to $38 \%$ in As-Suwayq. The fresh water zone $\left(<2 \mathrm{dS} \cdot \mathrm{m}^{-1}\right)$ in both areas has decreased to $0 \mathrm{~km}^{2}$ in 2005 . Given that most greenhouse growers in Oman use soil-based cultivation techniques (ICARDA, 2002) and that irrigation water with an electrical conductivity $(\mathrm{ECw})$ value greater than $1.5 \mathrm{dS} \cdot \mathrm{m}^{-1}$ (equivalent to $1.5 \mathrm{mmhos} \cdot \mathrm{cm}^{-1}$ ) is considered poor quality for most greenhouse crops. Salinization clearly has the potential to be a third major driving force 
for land use change.

Under investigation is the proposal that externalities have influenced greenhouse expansion projects. Specifically, a series of testable hypotheses are established to determine the extent, if any, of attraction or repulsion effects from (1) proximity to local markets and population centers, (2) irrigation water salinity and proximity to the coast (and thus higher groundwater salinities) (3) urban expansion and (4) transport infrastructure (Barka district only). Future agricultural zone planning for land use change depends on current knowledge of the spatial distribution of new greenhouse developments and an intuitive understanding of the sustainability of high densities of greenhouses in certain areas. To achieve this it is necessary at an early stage, to observe and monitor land change to gain an understanding of these changes as a coupled human-environment system, prior to the development of spatially explicit models of land change (Turner et al., 2007). As Amanor and Pabi (2007) have pointed out, land use change is unlikely to be represented by a simple or linear evolution but is more probably represented by complex interactions between human and environmental influences, including spatial and temporal oscillations between extensive and intensive agriculture.

In the current study only those districts through which the current coastal highway passes were included. This coastal highway links Muscat with Shinas, leads onward to Dubai and Abu Dhabi in the UAE and locally spawns numerous off-shoots, especially in those Wilaya closest to Muscat. The coastal highway represents an infrastructure interface and therefore its impact on local land use change could be significant (Lambin et al., 2000). These Wilaya also have rapidly changing ground-

Table 1. Number and area of active farms and numbers of greenhouses (2001 - 2009), newly active farms (2004 - 2009) and farms abandoned (2004 - 2009) in each Wilayat (figures in brackets represent percent of total).

\begin{tabular}{|c|c|c|c|c|c|c|c|}
\hline & 2001 & 2002 & 2003 & 2004 & 2009 & New & Abandoned \\
\hline \multicolumn{8}{|c|}{ Farm number } \\
\hline Barka & $30(-49.2)$ & $52(-57.1)$ & $54(-54)$ & $69(-56.1)$ & $105(-49.5)$ & $51(-41.8)$ & $18(57.8)$ \\
\hline Al Musanaah & $5(-8.2)$ & $8(-8.8)$ & $9(-9)$ & $9(-13)$ & $23(-10.8)$ & $17(-13.9)$ & $1(8.9)$ \\
\hline As Suwayq & $5(-8.2)$ & $5(-5.5)$ & $7(-7)$ & $9(-13)$ & $33(-15.6)$ & $25(-20.5)$ & $0(0)$ \\
\hline Al Khaburah & $7(-11.5)$ & $7(-7.7)$ & $8(-8)$ & $12(-9.8)$ & $15(-7.1)$ & $7(-5.7)$ & $5(-11.1)$ \\
\hline Saham & $6(-9.8)$ & $9(-9.9)$ & $9(-9)$ & $10(-8.1)$ & $18(-8.5)$ & $9(-7.4)$ & $1(-4.4)$ \\
\hline Sohar & $4(-6.6)$ & $5(-5.5)$ & $5(-5)$ & $5(-4.1)$ & $10(-4.7)$ & $6(-4.9)$ & $1(-2.2)$ \\
\hline Liwa & $1(-1.6)$ & $1(-1.1)$ & $1(-1)$ & $3(-2.4)$ & $3(-1.4)$ & $2(-1.6)$ & $2(-4.4)$ \\
\hline Shinas & $3(-4.9)$ & $4(-4.4)$ & $6(-6)$ & $5(-4.1)$ & $5(-2.4)$ & $5(-4.1)$ & $5(-11.1)$ \\
\hline Total & 61 & 91 & 100 & 123 & 212 & 122 & 45 \\
\hline \multicolumn{8}{|c|}{ Greenhouse number } \\
\hline Barka & $133(-43.8)$ & $340(-58.2)$ & $362(-57.7)$ & $458(-60.6)$ & $825(-51.5)$ & $402(-50.6)$ & $182(-56.9)$ \\
\hline Al Musanaah & $22(-7.2)$ & $63(-10.8)$ & $64(-10.2)$ & $64(-8.5)$ & $130(-8.1)$ & $82(-10.3)$ & $82(-25.6)$ \\
\hline As Suwayq & $16(-5.3)$ & $16(-2.7)$ & $19(-3)$ & $31(-4.1)$ & $292(-18.2)$ & $153(-19.3)$ & $0(0)$ \\
\hline Al Khaburah & $51(-16.8)$ & $49(-8.4)$ & $50(-8)$ & $56(-7.4)$ & $130(-8.1)$ & $29(-3.6)$ & $9(-2.8)$ \\
\hline Saham & $38(-12.5)$ & $58(-9.9)$ & $59(-9.4)$ & $61(-8.1)$ & $111(-6.9)$ & $46(-5.8)$ & $6(-1.9)$ \\
\hline Sohar & $30(-9.9)$ & $32(-5.5)$ & $27(-4.3)$ & $32(-4.2)$ & $75(-4.7)$ & $46(-5.8)$ & $4(-1.3)$ \\
\hline Liwa & $2(-0.7)$ & $2(-0.3)$ & $2(-0.3)$ & $14(-1.9)$ & $7(-0.4)$ & $6(-0.8)$ & $1(-0.3)$ \\
\hline Shinas & $12(-3.9)$ & $24(-4.1)$ & $42(-6.7)$ & $36(-4.8)$ & $31(-1.9)$ & $31((3.9))$ & $36(-11.3)$ \\
\hline Total & 304 & 584 & 627 & 756 & 1601 & 795 & 320 \\
\hline \multicolumn{8}{|l|}{ Farm area } \\
\hline Barka & $763.8(-62.3)$ & $860.3(-61.2)$ & $871.1(-58)$ & $1179.1(-56.1)$ & $1246.5(-33.3)$ & $533.5(-24.2)$ & $466(-82.2)$ \\
\hline Al Musanaah & $43.9(-3.6)$ & $77.7(-5.5)$ & $90.3(-6)$ & $90.3(-4.3)$ & $265.2(-7.1)$ & $205.7(-9.3)$ & $30.9(-5.4)$ \\
\hline As Suwayq & $278.3(-22.7)$ & $278.3(-19.8)$ & $331.4(-22.1)$ & $393(-18.7)$ & $880.8(-23.5)$ & $487.8(-22.1)$ & $0(0)$ \\
\hline Al Khaburah & $46(-3.8)$ & $68.7(-4.9)$ & $68.7(-4.6)$ & $92(-4.4)$ & $138.8(-3.7)$ & $66.9(-3)$ & $20.1(-3.5)$ \\
\hline Saham & $52.7(-4.3)$ & $72.5(-5.2)$ & $94.2(-6.3)$ & $107.3(-5.1)$ & $162.4(-4.3)$ & $70(-3.2)$ & $14.8(-2.6)$ \\
\hline Sohar & $21.4(-1.7)$ & $21.4(-1.5)$ & $21.4(-1.4)$ & $203.3(-9.7)$ & $977.3(-26.1)$ & $777.5(-35.2)$ & $3.4(-0.6)$ \\
\hline Liwa & $6.2(-0.5)$ & $6.2(-0.4)$ & $0(0)$ & $10.9(-0.5)$ & $21.5(-0.6)$ & $17.3(-0.8)$ & $6.7(-1.2)$ \\
\hline Shinas & $13.4(-1.1)$ & $21.5(-1.5)$ & $25.2(-1.7)$ & $25.2(-1.2)$ & $49.9(-1.3)$ & $49.9(-2.3)$ & $25.2(-4.4)$ \\
\hline Total & 1225.7 & 1406.5 & 1502.2 & 2101 & 3742.4 & 2209 & 567.1 \\
\hline
\end{tabular}



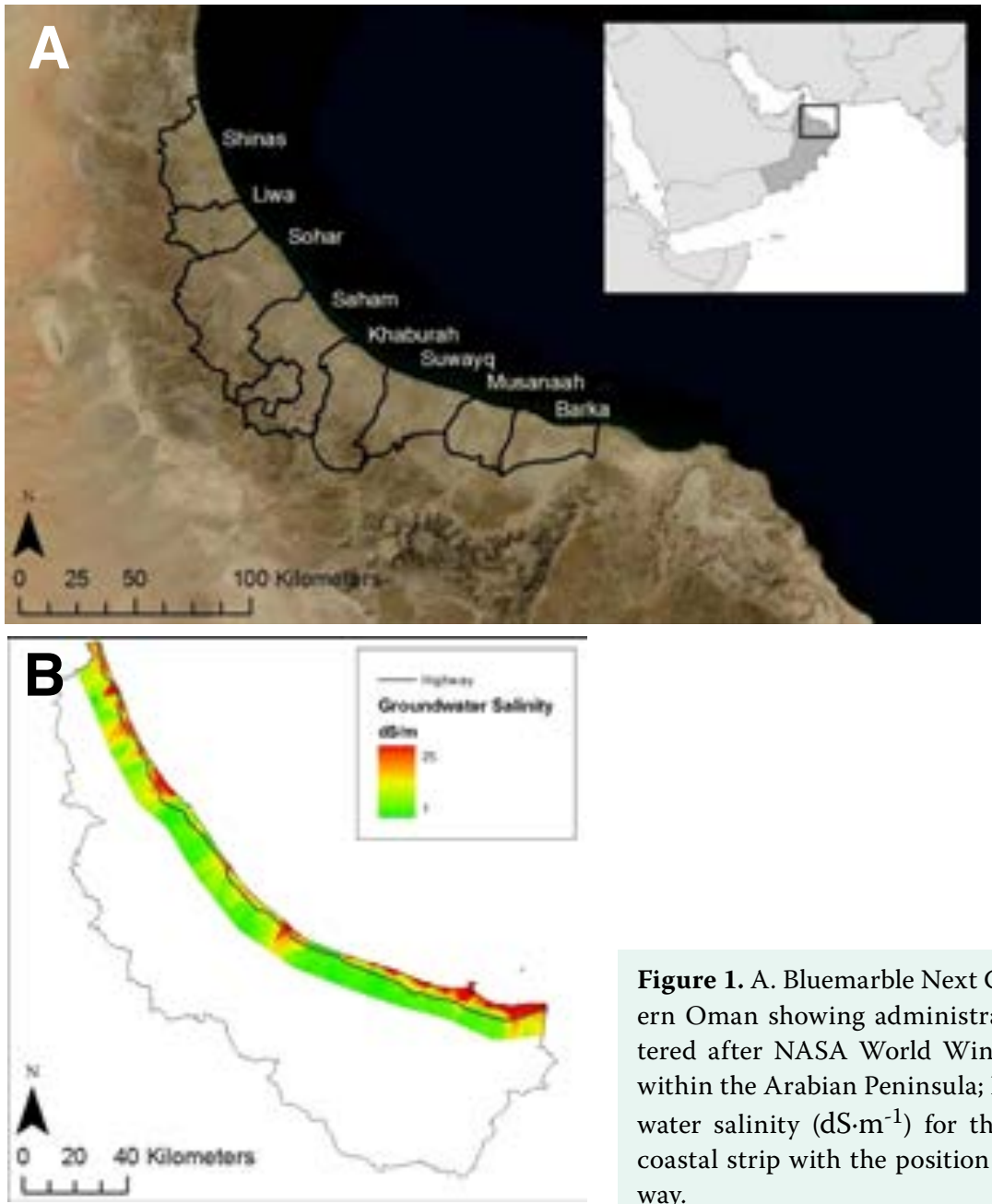

water salinity (Fig. 1b) as well as pressures of land use change through urbanization. They are also the districts within which over $95 \%$ of greenhouses in $\mathrm{Al}$ Batinah are located.

\section{Materials and methods}

In 2001, 2002, 2003, 2004 and 2009, a GPS unit was used to collect geospatial information about each farm with active greenhouses in each Wilayat. For each farm the number of productive greenhouses was recorded. During each survey note was taken of new farms and of farms that had been abandoned since the previous survey. For a random selection of 100 farms in the 2009

Figure 1. A. Bluemarble Next Generation image of Northern Oman showing administrative districts (Waliya) (altered after NASA World Wind); inset shows study area within the Arabian Peninsula; B. Kriged model of groundwater salinity $\left(\mathrm{dS} \cdot \mathrm{m}^{-1}\right)$ for the $30 \mathrm{~km}$ wide $\mathrm{Al}$ Batinah coastal strip with the position of the existing main highway.

survey, location and greenhouse number was verified against Google Earth ${ }^{\oplus}$ satellite imagery. All farm boundaries were fixed and farm sizes determined within Google Earth ${ }^{\circ}$. Within the GIS environment, Wilaya boundary information was used to separate farms into the various administrative districts (Fig. 1a) and Al Mawaleh central market was used as a fixed reference point for distance calculations. Distances from the entrance of each farm to the nearest paved road were similarly estimated.

Table 2. Logistic model estimates for distance (nearest $\mathrm{km}$ ) to $50 \%$ of cumulative farm, greenhouse number and farm area from Al-Mawaleh central market.

\begin{tabular}{|c|c|c|c|c|c|c|c|}
\hline & 2001 & 2002 & 2003 & 2004 & 2009 & New farms & Abandoned farms \\
\hline $\begin{array}{l}\% \text { Farms } \\
\left(\mathrm{R}^{2}, \mathrm{p}\right)\end{array}$ & $\begin{array}{l}42 \\
(.912,0.001)\end{array}$ & $\begin{array}{l}47 \\
(.943,0.001)\end{array}$ & $\begin{array}{l}49 \\
(.948,0.001)\end{array}$ & $\begin{array}{l}51 \\
(.963,0.001)\end{array}$ & $\begin{array}{l}60 \\
(.989,0.001)\end{array}$ & $\begin{array}{l}65 \\
(.987,0.001)\end{array}$ & $\begin{array}{l}46 \\
(.890,0.01)\end{array}$ \\
\hline $\begin{array}{l}\text { \% Greenhouses } \\
\left(\mathrm{R}^{2}, \mathrm{p}\right)\end{array}$ & $\begin{array}{l}48 \\
(.884,0.001)\end{array}$ & $\begin{array}{l}53 \\
(.968,0.001)\end{array}$ & $\begin{array}{l}55 \\
(.971,0.001)\end{array}$ & $\begin{array}{l}54 \\
(.968,0.001)\end{array}$ & $\begin{array}{l}57 \\
(.985,0.001)\end{array}$ & $\begin{array}{l}56 \\
(.980,0.001)\end{array}$ & $\begin{array}{l}38 \\
(.760,0.05)\end{array}$ \\
\hline $\begin{array}{l}\text { \% Farm area } \\
\left(\mathrm{R}^{2,} \mathrm{p}\right)\end{array}$ & $\begin{array}{l}42 \\
(.927,0.001)\end{array}$ & $\begin{array}{l}44 \\
(.945,0.001)\end{array}$ & $\begin{array}{l}47 \\
(.946,0.001)\end{array}$ & $\begin{array}{l}54 \\
.964,0.001)\end{array}$ & $\begin{array}{l}81 \\
(.929,0.001)\end{array}$ & $\begin{array}{l}93 \\
(.889,0.01)\end{array}$ & $\begin{array}{l}27 \\
(.720,0.05)\end{array}$ \\
\hline
\end{tabular}




\section{Proximity to local markets, population centres and the coast}

The sigmoidal cumulative percent farm number, farm area and cumulative percent greenhouse number at increasing distances from $\mathrm{Al}$ Mawaleh within Muscat were calculated and modeled using a logistic function (Equ. 1) to estimate numbers of farms and greenhouses within fixed distance intervals.

$$
y=k\left(1-b \mathrm{e}^{(-r x)}\right)
$$

Where $y$ is the estimated number of farms or greenhouses; $\mathrm{k}$ is the upper asymptote here fixed to $100 \%$; $\mathrm{b}$ and $\mathrm{r}$ are constants of regression and $\mathrm{x}$ is distance from $\mathrm{Al}$ Mawaleh market.

\section{Proximity to and effects of groundwater salinity}

Farm number, farm area and greenhouse number within $1 \mathrm{~km}$-wide intervals from the coast were calculated in GIS. Because greenhouse numbers were skewed towards the coast, cumulative sigmoidal totals were fit to the Gompertz function as an asymmetric sigmoidal model with a point of inflection at 100/e (Equ. 2).

$$
y=k\left(e^{(-b e(-x x))}\right)
$$

Where $\mathrm{y}, \mathrm{k}, \mathrm{b}, \mathrm{r}$ and $\mathrm{x}$ are as in equation 1 .

During the 2004 survey, irrigation water was collected from all farms with active greenhouses and water salinity (ECw) was measured. In 2005, Ministry of Regional Municipalities and Water Resources' data for 937 monitoring wells and boreholes was kriged within ArcGIS 9.3 3-D analyst, using the ordinary kriging method with a spherical model, to provide spatial information on estimated groundwater salinity $\left(\mathrm{dS} \cdot \mathrm{m}^{-1}\right.$, Fig. $\left.1 \mathrm{~b}\right)$. This enabled correlations to be made between kriged groundwater salinity for farm locations and salinity of collected irrigation water samples to determine likelihood values for the use of water resources by farmers alternate to groundwater supplies.

\section{The special case of Wilayat Barka}

Given the proximity of Wilayat Barka to Muscat and the disproportionately large number of greenhouses in that district, a detailed study was conducted to examine the interactions between farm and greenhouse location and changing salinity levels, urbanization and infrastructure development. Cumulative farm and greenhouse number and farm area was related to distance from Muscat (Al Mawaleh) and the northern coast and to kriged groundwater salinity. In addition, areas of individually identified parcels of urban land were estimated for 2005 using Landsat ETM+ imagery and 2009 using Google Earth $^{\circ}$ images to provide GIS-based data. Cumulative urban area was modeled using the logistic function (Equ. 1). Farm and greenhouse distribution relative to the network of paved roads was quantified by buffering roads to provide distances between farm entrance and the nearest paved road. Finally, a network of $500 \mathrm{~m}^{2}$ grids was used to cover the surface area of Wilayat Barka and urban and farmland land use cover was estimated from satellite imagery data for 2005 and 2009 (urban area) and 2004 and 2009 (farm area).

\section{Results}

\section{Farm and greenhouse numbers and farm area}

During the study period the number of farms with greenhouses in Al-Batinah increased from 61 in 2001 to 212 in 2009 and the total number of greenhouses over the same period increased from 304 in 2001 to 1601 in 2009 (Table 1). The mean number of greenhouses per farm was 4.98 in 2001, increasing to 7.53 in 2009 . In 2001 almost $30 \%$ of farms (19/61) had only a single greenhouse; in 2009 the modal greenhouse number had increased to 4.0. In 2001 only 8 farms had more than 10 greenhouses (maximum $=25)$, in 200953 farms had more than 10 greenhouses (maximum $=54$ ). Furthermore, of the 9 farms with 30 or more greenhouses in 2009 , more than half of these had commenced greenhouse crop production post 2001. Between 2004 and 200932 farms ceased greenhouse crop production, removing 320 greenhouses from the productivity arena (Table 1 ). The highest

Table 3. Gompertz model estimates for distance (nearest $0.1 \mathrm{~km}$ ) to $50 \%$ of cumulative farm, greenhouse number and farm area from the northern coast of Oman.

$\begin{array}{llllllll} & \mathbf{2 0 0 1} & \mathbf{2 0 0 2} & \mathbf{2 0 0 3} & \mathbf{2 0 0 4} & \mathbf{2 0 0 9} & \text { New farms Abandoned farms } \\ \text { \% Farms } & 5.0 & 5.1 & 5.1 & 5.2 & 5.3 & 5.2 & 4.5 \\ \left(\mathrm{R}^{2}, \mathrm{p}\right) & (.992,0.001) & (.990,0.001) & (.988,0.001) & (.990,0.001) & (.996,0.001) & (.999,0.001) & (.990,0.001) \\ \text { \% Greenhouses } & 5.0 & 5.1 & 5.1 & 5.2 & 5.6 & 5.8(.982, & 4.3(.982,0.001) \\ \left(\mathrm{R}^{2}, \mathrm{p}\right) & (.990,0.001) & (.991,0.001) & (.992,0.001) & (.990,0.001) & (.990,0.001) & 0.001) & 4.2(.977,0.01) \\ & 4.7 & 4.8 & 4.8 & 4.9 & 4.5 & 4.1 & (.982,0.01) \\ \text { \% Farm area } & (.984,0.001) & (.984,0.001) & (.985,0.001) & (.985,0.001) & (.992,0.001) & (.9 .5 & \\ \left(\mathrm{R}^{2}, \mathrm{p}\right) & & & & & 5.5^{\mathrm{a}} & 5.3^{\mathrm{a}} & \\ & & & & & (.998,0.001) & (.996,0.001)\end{array}$

${ }^{a}$ Recalculation following exclusion of two farms (see text for details) 
Table 4. Percent farm number, greenhouse number and farm area with kriged groundwater salinities above $4.2 \mathrm{dS} \mathrm{m}^{-1}$, based on cumulative totals at increasing estimated salinities.

$\begin{array}{llllllll} & \mathbf{2 0 0 1} & \mathbf{2 0 0 2} & \mathbf{2 0 0 3} & \mathbf{2 0 0 4} & \mathbf{2 0 0 9} & \text { New farms } & \text { Abandoned farms } \\ \text { \% Farms } & 60.8 & 55.8 & 55.2 & 52.0 & 37.2 & 32.5 & 67.3 \\ \left(\mathrm{R}^{2}, \mathrm{p}\right) & (.995,0.001) & .995,0.001) & (.995,0.001) & (.997,0.001) & (.996,0.001) & (.996,0.001) & .990,0.001) \\ \text { \% Greenhouses } & 45.3 & 37.6 & 37.4 & 36.9 & 22.1 & 22.9 & 60.6 \\ \left(\mathrm{R}^{2}, \mathrm{p}\right) & (.984,0.01) & (.984,0.01) & (.988,0.01) & (.987,0.01) & (.998,0.001) & (.998,0.001) & (.963,0.05) \\ \text { \% Farm area } & 53.3 & 49.9 & 48.2 & 39.8 & 14.3 & 12.7 & 74.1 \\ (\mathrm{R} 2, \mathrm{p}) & (.933,0.05) & (.940,0.05) & (.940,0.05) & (.944,0.05) & (.989,0.01) & (.975,0.01) & (.882,0.01)\end{array}$

level of abandonment was in Barka (57.8\% of all abandonments), followed by Al Khaburah and Shinas (11.1\%) and then $\mathrm{Al}$ Musanaah (8.9\%). The 2009 results showed that the majority $(62 \%)$ of farms with greenhouses had land areas less than 10 ha (Fig. 2); less than 3\% of farms were larger than 50 ha. Of particular relevance here is the overall decline in the preeminence of Barka in terms of farm number, declining from a high of $57 \%$ of all farms in 2002 to less than $50 \%$ of farms in 2009 (Table 1). This decline was reflected in the relatively low number (41.8\%) of new-start farms in this district contained with a large proportion of total farm abandonments (57.8\%). Although over $50 \%$ of new greenhouses were located in Barka, this represented less than $25 \%$ of new farm area, suggesting the development of relatively small farms with heavy emphasis on protected agriculture. Eighteen farms (representing $57.8 \%$ of the total) were abandoned in Barka, this represented $82.2 \%$ of the total agricultural land area lost between 2004 and 2009, representing relatively large farming areas. The situation for new farm developments in Sohar shows an opposite trend to that for Barka. In terms of land area, farms in Sohar represented $26.1 \%$ of total area in 2009 and $35.2 \%$ of total land area brought into protected agriculture between 2004 and 2009. Comparatively, the number of farms and greenhouses in Sohar in 2004 and 2009 was low; a small number of large, but diversified, farms are now operating in this district. Two further observations warrant comment. A high proportion of farm abandonments were in Shinas (11.1\% of total farm number and $11.3 \%$ of total greenhouse number), yet the contribution of these farms to total abandoned farm area was low (4.4\%), suggesting the loss of small farms with high greenhouse to land area ratios. Secondly, there was a significant increase in the prominence of As Suwayq district. In 2002 As-Suwayq accounted for $5.5 \%$ of farms and $2.7 \%$ of greenhouses; by 2009 the same district accounted for $15.6 \%$ of total farm

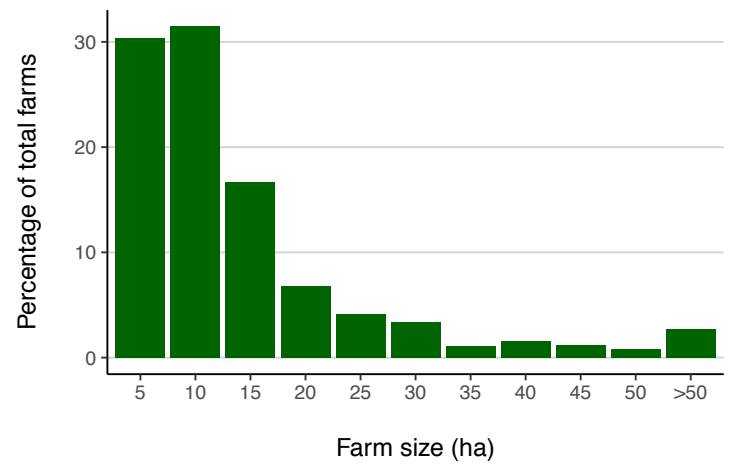

Figure 2. Frequency distribution of land area for farms with greenhouses in Al Batinah region.

number and $18.2 \%$ of total greenhouse number. New start farms in As Suwayq represented 20.5\% of total new farms and $19.3 \%$ of newly constructed greenhouses on these new farms and between 2004 and 2009 no farms were abandoned in As Suwayq (Table 1).

\subsection{Proximity to Muscat}

Based on the fitted logistic model, the estimated distance from Muscat (Al Mawaleh market) to 50\% (half distance) of cumulative number of farms, number of greenhouses and total land area for the years of the survey, together with half distances for new (between 2004 and 2009) and abandoned (post 2004) farms are shown in table 2. The half distance for all indicators extended to greater distances from Muscat during the period between 2001 and 2009 - from 42 to $60 \mathrm{~km}$, from 48 to $57 \mathrm{~km}$ and from 42 to $81 \mathrm{~km}$ respectively for farm number, greenhouse number and total farm area, respectively. This appears to indicate a movement westwards (away from Muscat) of active greenhouse crop production and is reflected in the half distances for farm number, greenhouse number and farm area for new farms which were 65, 56 and 93 $\mathrm{km}$ respectively, whilst those for abandoned farms were

Table 5. Logistic model estimates for distance (nearest km, within Wilayat Barka) to $50 \%$ of cumulative farm, greenhouse number and farm area from Al Mawaleh central market.

$\begin{array}{lllll} & \mathbf{2 0 0 4} & \mathbf{2 0 0 9} & \text { New farms } & \text { Abandoned farms } \\ \text { \% Farms }\left(\mathrm{R}^{2}, \mathrm{p}\right) & 28(.961,0.01) & 29(.945,0.05) & 29(.933,0.05) & 25(.977,0.01) \\ \text { \% Greenhouses }\left(\mathrm{R}^{2}, \mathrm{p}\right) & 28(.963,0.01) & 29(.944,0.05) & 26(.948,0.05) & 27(.935,0.05) \\ \text { \% Farm area }\left(\mathrm{R}^{2}, \mathrm{p}\right) & 28(.941,0.05) & 31(.939,0.05) & 31(.933,0.05) & 24(.922,0.05)\end{array}$




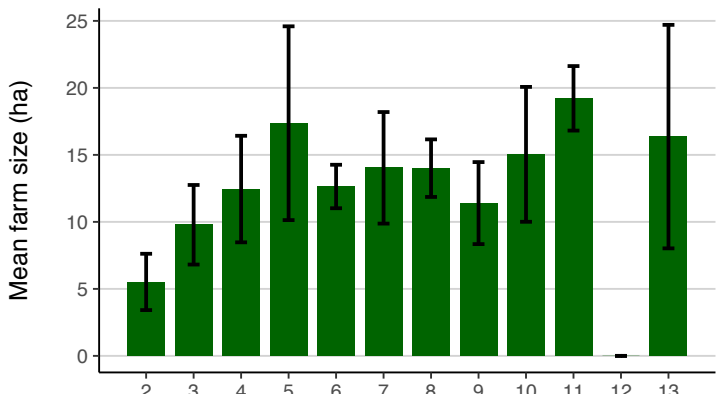

Distance from the coast $(\mathrm{km})$

Figure 3. Mean farm size in Al-Batinah region in relation to distance from the northern coast of Oman.

46, 38 and $27 \mathrm{~km}$. For all years and categories and for all indicators, the exponential model was an accurate and significant fit for the data (Table 2). The data in table 2 appear to corroborate that of table 1 and would fit with an increase in the relative contribution of farms in the As Suwayq district and a decrease for Wilayat Barka, especially over the latter part of the survey period.

\subsection{Distance from the coast and groundwater salinity}

Based on the 2009 data there was an increase in mean farm size with increased distance from the coast; farms adjacent to the coast had a mean area of 5.5 ha whilst those $5 \mathrm{~km}$ distant from the coast had a mean area of 17.4 ha. Beyond $5 \mathrm{~km}$ there was relatively little discernable change in mean farm size (Fig. 3).

For all years and for new and abandoned farms and for farm number, greenhouse number and farm area the fit of the Gompertz model was a significant reflection of the collected data (Table 3). Both estimated farm num-

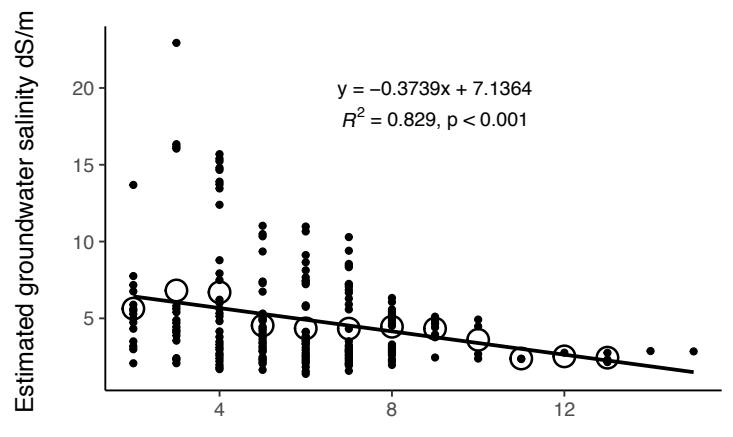

Distance from the coast $(\mathrm{km})$

Figure 4. Kriged groundwater salinities for farm locations (small circles) in Al-Batinah region relative to distance from the coast. Large circles represent mean farm size for each $1 \mathrm{~km}$ interval.

ber and greenhouse number half distances increased between 2001 and 2009 from 5.0 to 5.3 and from 5.0 to $5.6 \mathrm{~km}$ respectively, reflecting the southward movement of active protected agriculture production. In the case of farm area, the half distance decreased from $4.7 \mathrm{~km}$ in 2001 to $4.5 \mathrm{~km}$ in 2009 , with a half distance of $4.1 \mathrm{~km}$ for new farms. This was primarily a consequence of two farm (ID 173 and ID 174), located 2 and $3 \mathrm{~km}$ from the coast, and with areas of 182 ha and 756 ha respectively commencing production in the Wilayat of Sohar, some $168 \mathrm{~km}$ and $170 \mathrm{~km}$ distant from Al Mawaleh in regions only moderately affected by salinity (Table 1 ). When these farms are excluded from the analysis the half distance for 2009 farms increased to $5.5 \mathrm{~km}$ and for new farms it increased to $5.3 \mathrm{~km}$ (Table 3). Farms close to the coast contributed disproportionately to the number of abandoned farms (50\% within $4.5 \mathrm{~km})$, loss of greenhouses $(4.3 \mathrm{~km})$ and loss of farm area $(4.2 \mathrm{~km})$.

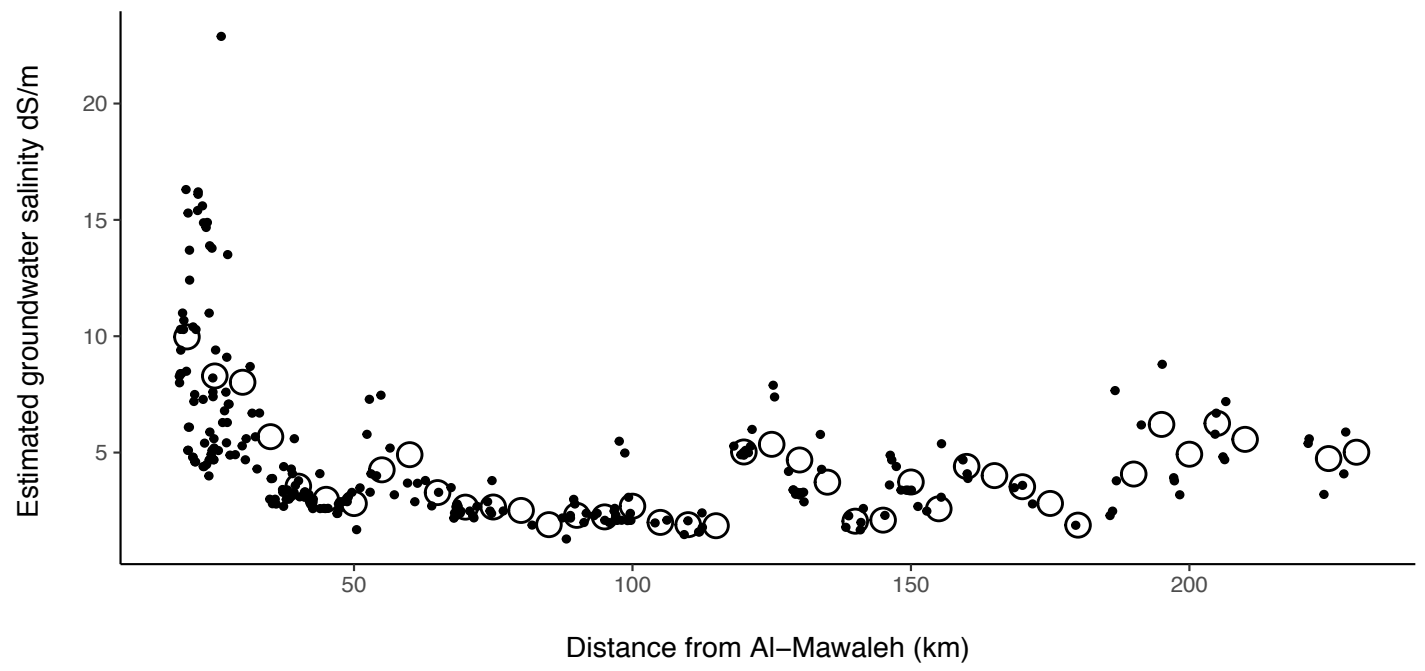

Figure 5. Kriged groundwater salinity values for farm locations in Al-Batinah region (small circles) in relation to distance from Al-Mawaleh central Market. Large circles represent mean values for $5 \mathrm{~km}$ intervals. 
Table 6. Gompertz model estimates for distance (nearest $0.1 \mathrm{~km}$ ) to $50 \%$ of cumulative farm, greenhouse number and farm area from the northern coast of Oman in Wilayat Barka.

$\begin{array}{lllll} & 2004 & 2009 & \text { New farms } & \text { Abandoned farms } \\ \text { \% Farms }\left(\mathrm{R}^{2}, \mathrm{p}\right) & 6.2(.992,0.001) & 6.4(.996,0.001) & 6.3(.995,0.001) & 5.6(.985,0.001) \\ \text { \% Greenhouses }\left(\mathrm{R}^{2}, \mathrm{p}\right) & 6.2(.987,0.001) & 6.9(.994,0.001) & 7.1(.987,0.001) & 5.1(.979,0.01) \\ \text { \% Farm area (R2, p) } & 5.7(.988,0.001) & 6.6(.997,0.001) & 6.3(.996,0.001) & 4.3(.968,0.05)\end{array}$

Although the relationship between kriged groundwater salinity, based on kriged 2005 borehole data, and irrigation water salinity (2004) taken directly from greenhouses was significant $(\mathrm{p}=0.0004)$, irrigation water salinity was consistently lower than the estimated groundwater salinity ( $\mathrm{p}($ intercept $)<0.001)$, apparently confirming the widespread practice of importing potable water to supplement well water to minimize crop toxicity damage. There is no evidence to confirm that farm wells and boreholes are accessing the same depth of water.

The highest kriged groundwater salinity at farm locations was in excess of $20 \mathrm{dS} \cdot \mathrm{m}^{-1}$ (Fig. 4); many farms having salinity levels above $10 \mathrm{dS} \cdot \mathrm{m}^{-1}$. There was a significant $\left(\mathrm{R}^{2}=.829, \mathrm{p}<0.001\right)$ decrease in estimated farm mean groundwater salinity with increasing distance from the coast (Fig. 4).

Kriged groundwater salinity levels were also highest close to Muscat (Fig. 5). All farms having estimated salinities above $10 \mathrm{dS} \cdot \mathrm{m}^{-1}$ were within $25 \mathrm{~km}$ of Al Mawaleh. Further peaks of salinity (above $5 \mathrm{dS} \cdot \mathrm{m}^{-1}$ ) were observed at regular intervals along the Al Batinah coastal belt, especially at approximately 50, 125, 150 and 200 km from Al Mawaleh (Fig. 5). Groundwater salinity was lowest over a greater distance within As Suwayq

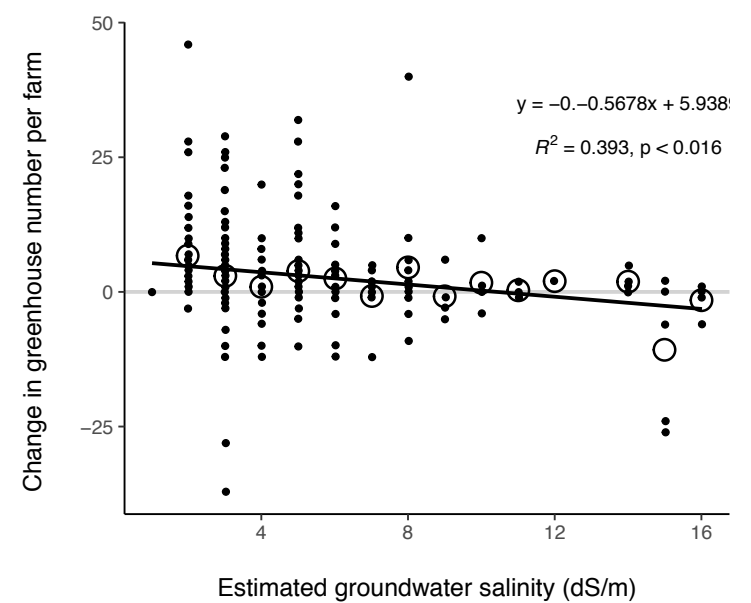

Figure 6. Change in number of greenhouses per farm between 2004 and 2009 (small circles) relative to increasing estimated groundwater salinity. Large circles represent the mean change in greenhouse number per farm for $1 \mathrm{dS} \cdot \mathrm{m}^{-1}$ intervals.
Wilayat, approximately $90-120 \mathrm{~km}$ from Al Mawaleh.

Based on kriged groundwater salinity levels calculated using 2005 borehole data (Fig. 1b), and the exponential model (Equ. 1), the proportion of farms with salinities above $4.2 \mathrm{dS} \cdot \mathrm{m}^{-1}$ where a $50 \%$ reduction in cucumber yield might be expected to occur (Ayers and Westcott, 1985 ) was $60.8,55.8,55.2,52.0$ and $37.2 \%$ in 2001,2002 , 2003, 2004 and 2009, respectively. Over $67 \%$ of farms abandoned between 2004 and 2009 had groundwater salinities above $4.2 \mathrm{dS} \cdot \mathrm{m}^{-1}$; less than $33 \%$ of new farms were located in such areas of high groundwater salinity (Table 4). In terms of total greenhouse number and total farm area, $60.6 \%$ of all abandoned greenhouses and $74.1 \%$ of abandoned land area was located in areas with salinities above the $50 \%$ yield reduction threshold $\left(4.2 \mathrm{dS} \cdot \mathrm{m}^{-1}\right)$; less than $23 \%$ of new greenhouses and less than $13 \%$ of the area of new farms were located in such regions. The average kriged groundwater salinity of new farms developed between 2004 and 2009 was $4.08 \mathrm{dS} \cdot \mathrm{m}^{-}$ 1; that of farms abandoned during the same period was $7.17 \mathrm{dS} \cdot \mathrm{m}^{-1}$.

Although increased groundwater salinity was understandably correlated with farm abandonment away from greenhouse production, it was also significantly related to the extent of direct investment in new protected cropping structures (Fig. 6). Farms located in regions with low estimated groundwater salinities showed significantly increased numbers of greenhouses per farm compared with those at sites where the groundwater salinity was higher. At $2 \mathrm{dS} \cdot \mathrm{m}^{-1}$ there was a net increase of almost 7 greenhouses per farm.

\subsection{The situation in Wilayat Barka}

The dynamics of land use change in Wilayat Barka are the most fluid: it is the district closest to Muscat and therefore most vulnerable to increasing demand for land use change to housing and industrial developments; it also has the most greenhouses (Table 1) despite having the highest groundwater salinity levels (Fig. 5), and has the most highly developed transport infrastructure (Fig. 7a). Within Barka, during the entire study period, there were 134 farms, including those abandoned during the study, occupying a total of 1729 ha and with over 1000 greenhouses. As of 2009 there were 825 greenhouses on 105 farms occupying almost 1250 ha. The majority of the active farms were located to the south of the coastal highway, and up to $14 \mathrm{~km}$ distant from the coast (Fig. 7b, Fig. 8). The farms that had been abandoned 
Table 7. Percent farm number, greenhouse number and farm area in Barka Wilayat with estimated groundwater salinities above $4.2 \mathrm{dS} \mathrm{m}-1$, based on cumulative totals at increasing salinities.

$\begin{array}{lllll} & \mathbf{2 0 0 4} & \mathbf{2 0 0 9} & \text { New farms } & \text { Abandoned farms } \\ \text { \% Farms }\left(\mathrm{R}^{2}, \mathrm{p}\right) & 58.0(.992,0.001) & 48.0(.989,0.001) & 46.8(.983,0.001) & 73.4(.988,0.001) \\ \text { \% Greenhouses }\left(\mathrm{R}^{2}, \mathrm{p}\right) & 57.8(.971,0.01) & 42.6(.988,0.001) & 44.3(.905,0.01) & 71.0(.981,0.001) \\ \text { \% Farm area (R2, p) } & 63.3(.911,0.01) & 41.5(.979,0.001) & 40.6(.788,0.05) & 88.7(.987,0.001)\end{array}$

between 2004 and 2009 were closer to the main highway and therefore closer to the northern coast of Oman, Figs. 7c, 7d, Fig. 8).

Using the Wilayat Barka data, the exponential change (equation 1) in farm and greenhouse number and farm area with increasing distance from $\mathrm{Al}$ Mawaleh was used to determine the distance within which $50 \%$ of the total of these parameters of agricultural activity occurred (Table 5). In all cases, the exponential model was a significant model of the observed change over distance and suggested that the abandonment of farms was proportionately higher closer to Muscat with $50 \%$ of abandoned farms being located within $25 \mathrm{~km}$ of $\mathrm{Al}$ Mawaleh, but $50 \%$ of all 2009 farms and $50 \%$ of new farms both being located within $29 \mathrm{~km}$ of Al Mawaleh. The model for greenhouse number showed a similar trend, with
$50 \%$ of greenhouses on abandoned farms being located closer to Al Mawaleh $(27 \mathrm{~km})$ than $50 \%$ of greenhouses on 2009 farms $(29 \mathrm{~km})$ although $50 \%$ of greenhouses on new farms were actually closer to Muscat $(26 \mathrm{~km})$ primarily because of the development of two new small farms (ID 191 and ID 4 with 40 and 32 greenhouses on 7.8 and 8.2 ha) located close to Al Mawaleh (19 and 21 $\mathrm{km}$ respectively) but some distance from the coast (8 and $9 \mathrm{~km}$, respectively). The model for farm area suggested the preferential abandonment of farms close to $\mathrm{Al}$ Mawaleh (50\% within $24 \mathrm{~km}$ ) whilst $50 \%$ of new farm area was within $31 \mathrm{~km}$ of Al Mawaleh. The new farms that emerged relatively close to Al Mawaleh were, however, further from the northern coast.

The data for Barka suggests the preferential abandonment of farms closer to the coast (Table 6). The thresh-
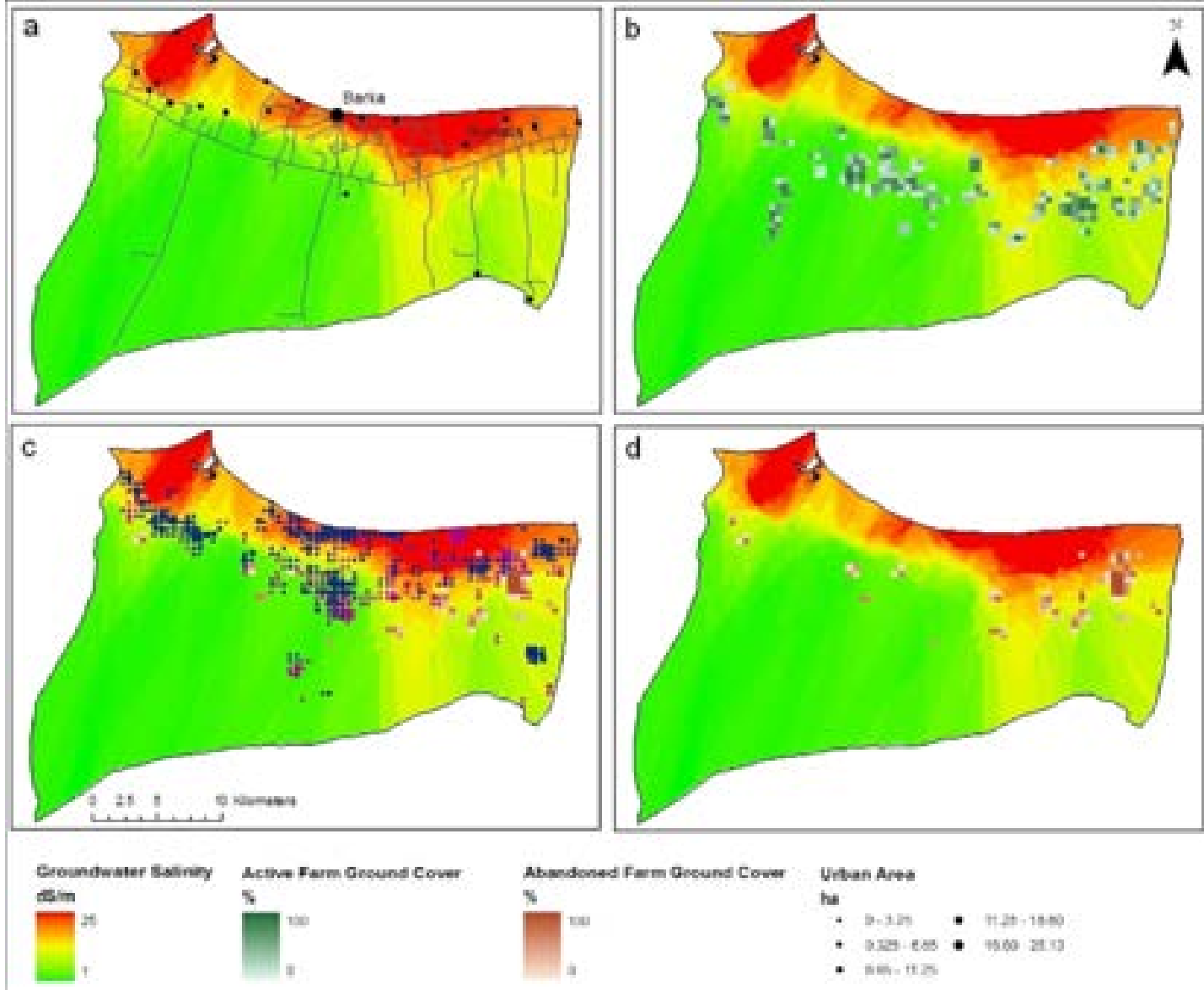

Figure 7. Map of Barka Wilayat showing groundwater salinity levels related to location of land abandoned to farming and recent urban developments. 
old of $50 \%$ of abandoned farm number, greenhouse number and farm area was located at 5.6, 5.1 and $4.3 \mathrm{~km}$ respectively, closer to the coast than for 2009 farms (6.4 6.9 and $6.6 \mathrm{~km})$ and farms developed between 2004 and 2009 (6.3, 7.1 and $6.3 \mathrm{~km}$, respectively).

Table 7 shows the apparent importance of groundwater salinity in determining farm abandonment and location of new farm developments. Over $73 \%$ of abandoned farms, $71 \%$ of the cumulative greenhouse numbers and $88.7 \%$ of the cumulative total abandoned farm areas were located in regions with estimated groundwater salinities in excess of $4.2 \mathrm{dS} \cdot \mathrm{m}^{-1}$. New farms were predominantly located in areas with lower $\left(<4.2 \mathrm{dS} \cdot \mathrm{m}^{-1}\right)$ groundwater salinities (only $46.8 \%$ of farms, $44.3 \%$ of greenhouses and $40.6 \%$ of total farm area was located in regions above $4.2 \mathrm{dS} \cdot \mathrm{m}^{-1}$ of ECw, Table 7).

The distribution of farms with active greenhouse crop production in 2009 follows closely the distribution of paved roads in Wilayat Barka (Figs 7a, 7b). This is true not only for the main highway, but also the minor roads heading south, away from the coast. The distribution of abandoned farms also appeared closely related to the pattern of transport infrastructure (Fig. 7d), especially those interior roads towards the eastern part of the district. In both cases, there was a significant relationship between exponential cumulative farm number and distance to paved roads $\left(\mathrm{R}^{2}>0.93, \mathrm{p}<0.001\right)$ with more than $50 \%$ of farm entrances being within $500 \mathrm{~m}$ of a paved road.

As of 2009, over 600 parcels of urban land were individually identified in Barka as housing developments, small industrial units, retail outlets and public service buildings. Most of this urban land was north of the coastal highway, between the road and the northern coast of Oman (Fig. 7c, Fig. 9). This contrasts significantly with the distribution of agricultural land (Fig. 8). An exponential model of cumulative total urban area relative to the coast suggested that $75 \%$ of the total was within $6.1 \mathrm{~km}$ of the coast $\left(\mathrm{R}^{2}=0.967, \mathrm{p}=0.001\right)$ and showed only a relatively small change from 2000 when $75 \%$ of the total was within $5.9 \mathrm{~km}$ of the coast $\left(\mathrm{R}^{2}=\right.$ 0.967, $\mathrm{p}=0.001$ ), suggesting urban infill rather than the development of new urban sites. This infill hypothesis is also reflected by the distribution of urban land relative to $\mathrm{Al} \mathrm{Mawaleh.} \mathrm{In} 2000,75 \%$ of the cumulative urban land area was within $43 \mathrm{~km}\left(\mathrm{R}^{2}=0.973, \mathrm{p}=0.001\right)$ whilst in 2009 the threshold distance was $40 \mathrm{~km}\left(R^{2}=0.974\right.$ $\mathrm{p}=0.001$ ), suggesting only a slight expansion of the urban area away from Muscat and this occurring with a linear trajectory, mostly between the border of Muscat and Barka town.

Analysis of the grid overlying Barka Wilayat (Figs. $7 \mathrm{a}-\mathrm{d}$ ) clearly shows the relationship between the kriged groundwater salinity data and active (2009) and abandoned farms (2004-2009). Although some active farms remain in high $\mathrm{ECw}$ areas, especially around A'Rumais village, most were in regions with much lower salinities,

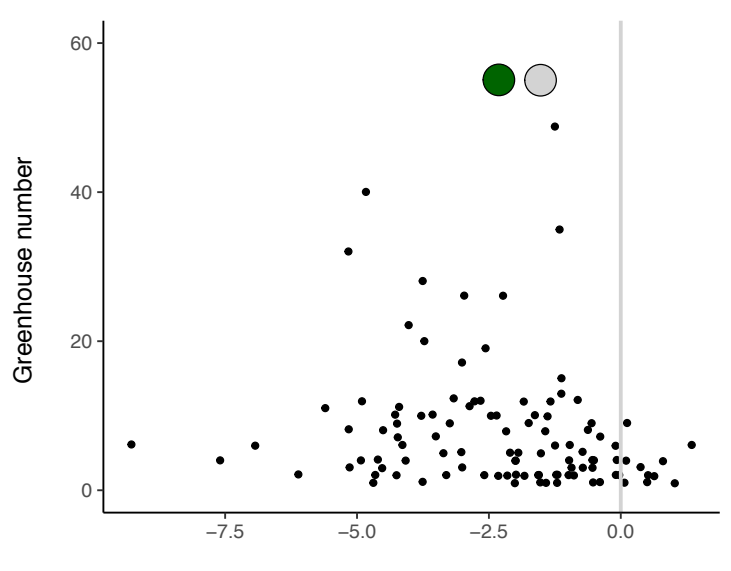

Distance from the main highway $(\mathrm{km})$

Figure 8. Number of greenhouses on farms in Barka Wilayat, Al-Batinah region, in relation to the position of the coastal highway. Positive and negative distances are north and south of the highway respectively. Large circles represent mean position relative to the coastal highway of active farms (2009, dark green) and abandoned farms (pre 2009, light grey).

and almost all are south of the highway. In contrast, the majority of abandoned farms are located in areas of high groundwater salinity either in the area close to the border with Muscat to the east, or within the zone of the high salinity tongue extending south from A'Rumais. The location of urban land cover follows closely the distribution of transport infrastructure, especially on the northern side of the highway and within the Barka town urban district (Fig. 7c). Figure 7c also appears to show that urban land cover largely occupies a different set of grid squares to those occupied by abandoned farms, and as such urban land cover does not represent a change in land use from agriculture, at least in terms of intensively farmed agricultural land lost since 2004. Urban expansion is, rather, seen as a complex mixture of infilling within regions of exceptionally high groundwater salinities close to the coast and ribbon development along the main highway. This notwithstanding, there remain, as of 2009 , extensive areas of land close to the coast where the groundwater salinity is extremely high but where urban development has not, so far, taken place.

\section{Discussion}

In the current paper greenhouse (protected) cropping is used as a proxy for high intensity agriculture. That greenhouse cropping systems are intensive means of food production may appear self-evident. They normally require large amounts of labour and capital per unit area of land per year and usually involve extending the growing season of crops (Jensen and Malter, 1995). The World Bank has promoted the development of green- 


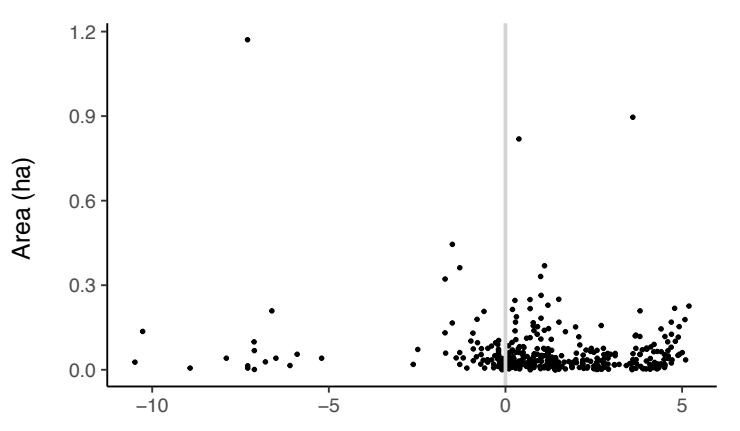

Distance from the main highway $(\mathrm{km})$

Figure 9. Distribution of urban land in Barka Wilayat, Al-Batinah region in relation to the position of the coastal highway. Positive distances and negative distances are north and south of the highway respectively.

house production systems through development aid, stating "the removal of trade barriers, coupled with growing consumer demand for quality produce all year round, has further stimulated this move towards high value, intensive forms of horticultural production" (Jensen and Malter, 1995). The sustainability of high intensity greenhouse production systems might be a less easily resolvable debate (Franze and Ciroth, 2011; Benito et al., 2009; Downward and Taylor, 2007), especially in arid and semi-arid regions where water availability for irrigation is often the limiting factor for agricultural development. In a life-cycle analysis of the environmental impact of greenhouse crop production systems, Muñoz et al. (2008) evaluated water consumption per $\mathrm{kg}$ of tomato as approximately $50 \%$ less for greenhouse production compared to open field production. Yet as Pandey et al. (2002) point out from a study in Niger, it is the appropriate use of agriculture intensification technology that is vital in sustainable, increased crop production. However, improvements in irrigation efficiency may merely induce growers to irrigate for longer (Peterson and Ding, 2005). Meanwhile, in the arid arena of Oman, the production intensification through greenhouse construction argument rests on the need to extend the growing season in a pincer movement, starting earlier after the end of summer and pushing the cessation of production later into the spring, relative to open field production. Unless water use efficiency is improved, more irrigation will be applied per year.

The results show that most farms with greenhouses are less than 10 ha (Fig. 2) and that mean farm size increases with distance from the coast (Fig. 3). Al Batinah is a region based on small farm cultivation and this has, in part been influenced by Islamic inheritance law whereby land is fragmented as it passes between generations (Zekri, 2010). Older farms are, in general, nearer to the coast and have thus been more fragmented over a longer period of time than more recently established farms inland. Alternatively, as Zekri (2010) suggests, other socio-economic causes of fragmentation exist, including the selling of parts of farms for urban development. The danger here is that continued fragmentation reduces agricultural sustainability (Fan and Chan-Kang, 2005).

When modeling the expansion of agriculture in Kenya's Eastern Arc Mountains, Maeda et al. (2010) identified the main factors driving the spatial distribution of land brought into agriculture as distance to markets, proximity to already established agricultural areas and distance to roads. The dominance of the Muscat capital area in determining the distribution of intensive agricultural production units is similarly apparent here. Although there was an outward extension, between 2004 and 2009 , of the distance within which $50 \%$ of cumulative farms $(42 \mathrm{~km}$ to $60 \mathrm{~km})$, greenhouses $(48 \mathrm{~km}$ to $57 \mathrm{~km})$ and farm area (42 km to $81 \mathrm{~km}$ ), and the $50 \%$ threshold for new farms developed between 2004 and 2009 was further from Muscat, the overwhelming majority of intensive agriculture remained close to the main market in Al Mawaleh (Table 2). Transport infrastructure was also a clear driver for land use: $50 \%$ of farms with greenhouses were within $500 \mathrm{~m}$ of the nearest paved road (Fig. 7b).

Notwithstanding the market and infrastructure drivers of land use for intensive (greenhouse) agricultural production, clustering of land use components was clear (see Fig. 7b for Wilayat Barka). Land use clustering is a well-documented social-spatial externality (Lewis et al., 2008) resulting from processes related to changes in information flows (diffusion of information, Foster and Rosenzweig, 1995) or imitation (Schmit and Rounsevell, 2006), transaction costs, fixed costs, infrastructure, and other factors. But clustering was also observed in abandonments away from intensive agriculture (Fig. 7d) and abandonments were disproportionately closer to Muscat; in this case the principal drivers are more likely to be biophysical, mediated through socio-economic, rather than purely socio-economic.

In Oman, there is little direct evidence of a linear momentum from agricultural land use to urban land use. Even in Barka, where urban pressures are greatest, Figure 7c shows that co-habitation by abandoned farms and urban land parcels within the individual 250,000 m2 (25 ha) cells superimposed on the Wilayat, is low. In Barka, the growth of urban developments has almost entirely been restricted to the strip of land between the existing highway and the coast (Figs. 1b, 7, 8, 9). This land area is mostly dominated by highly saline soils previously abandoned by productivist agriculture (Fig. 7d). As intensive agriculture has been driven out of what might be called a "saline corridor", it has been replaced by a mixture of land cover types, including urban developments and abandoned agricultural lands reclaimed by natural vegetation and quasi pre-productivist rural land use with extensively grazed goat herds dominating. In Southern Chile Diaz et al. (2011) recorded an almost 50\% level of agricultural land abandonment between 1985 and 2007 
in their study area, with important drivers of the return to arboreous shrubland being identified as, amongst others, soil quality. They also identified policy-driven subsidies as an important socio-economic factor behind land abandonment. It is clear that in the $\mathrm{Al}$ Batinah "saline corridor", soil salinity is the major driver of land use change, encouraging a trajectory towards abandonment; it is also possible that the continuing government subsidies offered to farmers in Oman for the construction of greenhouses are similarly driving the abandonment of land in marginal areas: growers are unlikely to expand the number of productive units when yields are at risk from high groundwater salinities unless expensive potable water is imported. In any case, in this area small farm size may also preclude expansion.

Recent literature has concentrated on land-use / land -cover as drivers of change in groundwater quality. Perhaps predictably, Singh et al. (2011) found that land use change towards urbanization and industrialization in Punjab, India resulted in a reduction in groundwater quality over 1989-2006. A similar outcome has been reported in Western Turkey (Sanli et al., 2009) although Twarakavi and Kaluarachchi (2006) reported an increase in groundwater quality when urbanization displaced agriculture as the dominant land use and levels of nitrate and other agrochemical residues declined. Xu et al. (2007) examined the impact of land use on changes in groundwater nitrate quantity using spatially integrated data during the 1960s to 1990 s. Not surprisingly nitrate levels rose as agriculture intensified and later fell as groundwater levels themselves dropped or land became urbanized. More interestingly vector differences in groundwater quality changes were observed for different land uses and land use changes (desert to agriculture, desert to urban and agriculture to urban). In Oman, the impact of intensive agriculture on groundwater quality close to the coast is already well documented, greater interest now lies in the consequent land use change trajectories. The government has adopted the expedient socio-economic position of responding to the decline in agriculture caused by the change in groundwater quality by introducing an industrialization or urbanization policy along the "salinity corridor", including the compulsory purchase of farm land. Whether this would have occurred in the absence of the groundwater quality change reducing the tenacity of intensive agriculture is debatable. What is clear is that the next decade is likely to bring urbanization and financial investment in infrastructure to Oman at a previously unseen scale. Major transport projects are planned for the "saline corridor"; these are certain to result in significant industrial and urban land use changes as an additional highway runs the length of the coast between the Wilaya of Barka and Shinas. Inland, a new highway and rail system is to be developed that is likely to attract urban development along the roads connecting these highways (Anonymous, 2010)
The results of the current study suggest an overall movement of the intensive agriculture (proxied by greenhouse developments) zone inland and away from Muscat (see Fig. 7b for Barka Wilayat vectors), away from the coast with its high soil salinity and following the improving internal transport infrastructure. The largest net change in recent intensive agricultural activity has been the increase, especially in terms of farm area, in Wilayat As Suwayq (Table 1). This district is the lowest in the apparent extent of groundwater salinity (Fig. 1b) and has the lowest percent area affected by salinities above $9 \mathrm{dSm}-1$ (Zekri, 2010). This momentum will need to be addressed at the socio-economic policy level to prevent a future decline of groundwater salinity in this district.

\section{Conclusion}

Oman is a rapidly changing country. A high rate of population growth and policy-driven industrial diversification away from petrochemicals is encouraging urbanization at the expense of traditional agriculture. Intensive agriculture appears to be responding by moving away from areas of most rapid urban change and away from areas of highest groundwater salinity: new, large farms are being developed inland as small, traditional farms close to the coast and close to Muscat are abandoned. This movement appears to be facilitated by expanding networks of transport infrastructure. For the first time in Oman the dynamics of the changing land use have been analyzed providing researchers and others with database information to explore other vectors for change in the agricultural sector.

\section{References}

Al-Barwani, A. and T. Helmi. 2006. Seawater intrusion in a coastal aquifer: A case study for the area between Seeb and Suwaiq, Sultanate of Oman. Sultan Qaboos University Journal for Agricultural and Marine Sciences 11:55-69.

Amanor, K.S. and O. Pabi. 2007. Space, time, rhetoric and agricultural change in the transition zone of Ghana. Human Ecology 35: 51-67.

Anonymous. 2010. Comprehenisive Master Plan for Al Batinah Coastal Area. Phase-1 Final Report: Analysis and Assessment of Study Area. Supreme Committee for Town Planning, Sultanate of Oman.

Armsworth, P.R., G.C. Daily, P. Kareiva, and J.N. Sanchirico. 2006. Land market feedbacks can undermine biodiversity conservation. Proceedings of the National Academy of Sciences of the United States of America 103: 5403-5408.

Asner, G.P., D.E. Knapp, E.N. Broadbent, P.J.C. Oliveira, M. Keller, and J.N. Silva. 2005. Selective logging in the Brazilian Amazon. Science 310: 480-482. 
Asseng. S., A. Dray, P. Perez, and X. Su. 2010. Rainfallhuman-spatial interactions in a salinity-prone agricultural region of the Western Australian wheat-belt. Ecological Modelling 221: 812-824.

Ayers, R.S. and D.W. Westcott. 1985. Water Quality for Agriculture. Irrigation and Drainage Paper 29. Rome, FAO. 174pp.

Benito, B.M., M.M. Martinez-Ortega, L.M. Munoz, J. Lorite, and J. Penas. 2009. Assessing extinction-risk of endangered plants using species distribution models: a case study of habitat depletion caused by the spread of greenhouses. Biodiversity and Conservation 18: 2509-2520.

CIA, 2010. The World Factbook. Central Intelligence Agency Office of Public Affairs. USA, Washington.

Diaz, G.I., L. Nahuelhual, C. Echeverria, and S. Marin. 2011. Drivers of land abandonment in Southern Chile and implications for landscape planning. Landscape and Urban Planning 99: 207-217.

Downward, S.R. and R. Taylor. 2007. An assessment of Spain's Programa AGUA and its implications for sustainable water management in the province of Almeria, southeast Spain. Journal of Environmental Management 82: 277-289.

Fan, S.G. and C. Chan-Kang. 2005. Is small beautiful? Farm size, productivity, and poverty in Asian agriculture. Agricultural Economics 32: 135-146.

Fasano, U. and Z. Iqbal. 2003. GCC Countries: From Oil Dependence to Diversification, Washington: International Monetary Fund.

Foster, A. and M. Rosenzweig. 1995. Learning by doing and learning from others: Human capital and technical change in agriculture. Journal of Political Economy 103: 1176-1209.

Franze, J. and A. Ciroth. 2011. A comparison of cut roses from Ecuador and the Netherlands. International Journal of Life Cycle Assessment 16: 366-379.

Ghassemi, F., A. Close, and J.R. Kellett. 1997. Numerical models for the management of land and water resources salinisation. Mathematics and Computers in Simulation 43: 323-329.

ICARDA. 2002. Integrated Management of Cucumber and Tomato Pests under Protected Cultivation Systems. Aleppo, International Center for Agricultural Research in the Dry Areas.

IMF. 2008. IMF Executive Board Concludes 2007 Article IV Consultation with Oman. International Monetary Fund Public Information Notice (PIN) No. 08/50, April 30, 2008.

Jensen, M.H. and A.J. Malter. 1995. Protected Agriculture: A Global Review. World Bank Technical Paper Number 253, World Bank, Washington, USA, 176 pp.

Kacimov, A.R., M.M. Sherif, J.S. Perret, and A. Al-Mu- shikhi. 2009. Control of sea-water intrusion by salt-water pumping: Coast of Oman. Hydrogeology Journal 17: 541-558.

Kotera, A., T. Sakamoto, D.K. Nguyen, and M. Yokozawa. 2008. Regional consequences of seawater intrusion on rice productivity and land use in coastal area of the Mekong river delta. Japan Agricultural Research Quarterly 42: 267-274.

Lambin, E.F., M.D.A. Rounsevell, and H.J. Geist. 2000. Are agricultural land use models able to predict changes in land use intensity? Agriculture, Ecosystems and Environment 82: 321-331.

Lambin, E.F., B.L. Turner, H.J. Geist, S.B. Agbola, A. Angelsen, J.W. Bruce, O.T. Coomes, R. Dirzo, G. Fischer, C. Folke, P.S. George, K. Homewood, J. Imbernon, R. Leemans, X.B. Li, E.F. Moran, M. Mortimore, P.S. Ramakrishnan, J.F Richards, H. Skanes, W. Steffen, G.D.Stone, U. Svedin, T.A. Veldkamp, C. Vogel, and J.C. Xu. 2001. The causes of land-use and land-cover change: moving beyond the myths. Global Environmental Change - Human and Policy Dimensions 11: 261-269.

Lewis, D.J., B.L. Barham, and K.S. Zimmerer. 2008. Spatial externalities in agriculture: Empirical analysis, statistical identification, and policy implications. World Development 36: 1813-1829.

Maeda, E.E., B.J.F. Clark, P. Pellikka, and M. Siljander. 2010. Modelling agricultural expansion in Kenya's Eastern Arc Mountains biodiversity hotspot. Agricultural Systems 103: 609-620.

MacLeod, C.J. and H. Moller. 2006. Intensification and diversification of New Zealand agriculture since 1960: An evaluation of current indicators of land use change. Agriculture Ecosystems and Environment 115: 201-218.

MAF. 1994. Planting Cucumber and Tomato in the Greenhouses. Muscat, Ministry of Agriculture and Fisheries.

Mottet, A., S. Ladet, N. Coque, and A. Gibon. 2006. Agricultural land-use change and its drivers in mountain landscapes: A case study in the Pyrenees. Agricultural Ecosystems and Environment 114:296-310.

Muñoz, P., A. Antón, M. Nuñez, A. Paranjpe, J. Ariño, X. Castell, J.I. Montero, and J. Rieradevall. 2008. Comparing the environmental impacts of greenhouse versus open-field tomato production in the Mediterranean region. Acta Horticulturae 801: 1591-1596.

MWR. 2000. National Water Resources Master Plan. Internal Report, October 2000. Ministry of Water Resources, Sultanate of Oman. 120pp.

Nepstad, D.C., A. Verissimo, A. Alencar, C. Nobre, E. Lima, P. Lefebvre, P. Schlesinger, C. Potter, P. Moutinho, E. Mendoza, M. Cochrane, and V. Brooks. 1999. Large-scale impoverishment of Amazonian forests by 
logging and fire. Nature 398:505-508.

Odedokun, M.O. 1996. Alternative econometric approaches for analysing the role of the financial sector in economic growth: Time-series evidence from LDCs. Journal of Development Economics 50: 119146.

Omar, S.A.S., T. Madouh, I. El-Bagouri, Z. Al-Mussalem, and H. Al-Telaihi. 1998. Land degradation factors in arid irrigated areas: The case of Wafra in Kuwait. Land Degradation and Development 9: 283-294.

Omezzine, A., O. Al-Jabri, and H. Boughanmi. 2002. Analysis of fruit and vegetable price integration between Al Mawaleh market and Dubai wholesale market. Agricultural and Fisheries Research Bulletin (Ministry of Agriculture and Fisheries, Muscat, Oman) 2: 5-10.

Pando-Moreno, M., E. Jurado, M. Manzano, and E. Estrada. 2004. The influence of land use on desertification processes. Journal of Range Management 57: 320-324.

Pandy, R.K., T.W. Crawford, and J.W., Maranville. 2002. Agriculture intensification and ecologically sustainable land use in Niger: A case study of evolution of intensive systems with supplementary irrigation. Journal of Sustainable Agriculture 20: 33-55.

Peterson, J.M. and Y. Ding. 2005. Economic adjustments to groundwater depletion in the high plains: Do water-saving irrigation systems save water? American Journal of Agricultural Economics 87: 147-159.

Sanli, F.B., Y. Kurucu, and M.T. Esetlili. 2009. Determining land use changes by radar-optic fused images and monitoring its environmental impacts in Edremit region of western Turkey. Environmental Monitoring and Assessment 151: 45-58.

Schmit, C. and M.D.A. Rounsevell. 2006. Are agricultural land use patterns influenced by farmer imitation? Agriculture, Ecosystems and Environment 115: 113-127.

Seto, K.C., R.K. Kaufmann, and C.E. Woodcock. 2000. Landsat reveals China's farmland reserves, but they're vanishing fast. Nature 406: 121.

Seto, K.C., C.E. Woodcock, C. Song, X. Huang, J. Lu, and R.K. Kaufmann. 2002. Monitoring land-use change in the Pearl River Delta using Landsat TM. International Journal of Remote Sensing 23: 1985-2004.

Seto, K.C., R. Sánchez-Rodríguez, and M. Fragkias. 2010. The new geography of contemporary urbaniza- tion and the environment. Annual Review of Environment and Resources 35: 167-94.

Singh, C.K., S. Shashtri, S. Mukherjee, R. Kumari, R. Avatar, A. Singh, and R.P. Singh. 2011. Application of GWQI to assess effect of land use change on groundwater quality in Lower Shiwaliks of Punjab: Remote sensing and GIS based approach. Water Resources Management 25: 1881-1898.

Turner, B.L., E.F. Lambin, and A. Reenberg. 2007. The emergence of land change science for global environmental change and sustainability. Proceedings of the National Academy of Sciences of the United States of America 104: 20666-20671.

Twarakavi, N.K.C. and J.J. Kaluarachchi. 2006. Sustainability of groundwater quality considering land use changes and public health risks. Journal of Environmental Management 81: 405-419.

UN. 2007. World Population Prospects: The 2006 Revision, Highlights, Working Paper No. ESA/P/WP.202. United Nations, Department of Economic and Social Affairs, Population Division.

Wilson, G.A. and J. Rigg. 2003. Post-productivist agricultural regimes and the south: discordant concepts? Progress in Human Geography 27: 681-707.

$\mathrm{Xu}$, Y., L.A. Baker, and P.C. Johnson. 2007. Trends in ground water nitrate contamination in the Phoenix, Arizona Region. Ground Water Monitoring and Remediation 27: 49-56.

Zekri, S. 2010. Agriculture. In: Comprehensive Master Plan for Al Batinah Coastal Area. Supreme Committee for Town Planning, Sultanate of Oman. 